\title{
ANALISIS FAKTOR-FAKTOR YANG MEMPENGARUHI PRODUKSI PEPAYA DI KECAMATAN KRUENG BARONA JAYA KABUPATEN ACEH BESAR
}

\author{
Analysis Affecting Factors Production of Papaya In District Krueng Barona Jaya Aceh \\ Besar
}

\author{
Satria $^{1}$, Zakiah $^{1}$, Romano $^{1^{*}}$ \\ ${ }^{1}$ Program Studi Agribisnis, Fakultas Pertanian, Universitas Syiah Kuala
}

\begin{abstract}
Abstrak. Dalam upaya meningkatkan produksi pepaya di Kecamatan Krueng Barona Jaya. Maka tujuan penelitian ini adalah untuk mengetahui faktor-faktor luas lahan, modal dan tenaga kerja dapat mempengaruhi produksi pepaya di Kecamatan Krueng Barona Jaya Kabupaten Aceh Besar. Metode penelitian yang digunakan adalah metode survey secara sengaja kepada seluruh populasi sampel (total sampling). Pengumpulan data dalam penelitian ini diperoleh dari dua sumber yaitu data primer dan data sekunder. Hasil penelitian menunjukkan analisis koefisiensi determinasi $\left(\mathrm{R}^{2}\right)$ diperoleh nilai sebesar 0,989 yang berarti bahwa luas lahan, modal, tenaga kerja mempengaruhi produksi pepaya sebesar $98,9 \%$, sedangkan sisanya 1,1\% dipengaruhi oleh faktor lain. Hasil analisis secara serempak (uji-f) bahwa faktor luas lahan, modal, tenaga kerja berpengaruh nyata terhadap produksi pepaya di Kecamatan Krueng Barona Jaya Aceh Besar. Analisis secara parsial (uji-t) menyatakan bahwa faktor luas lahan, modal, dan tenaga kerja berpengaruh nyata terhadap produksi pepaya.
\end{abstract}

Kata kunci: Faktor Produksi, Luas Lahan, Modal, Tenaga Kerja

\begin{abstract}
In order to increase production of papaya in district Krueng Barona Jaya. The purpose this study is to find some factors of their land, capital and labor can affect to papaya production in district Krueng Barona Jaya of Aceh Besar. The methodology used is the method intentional survey to the entire sample of population (total sampling). Data collection in this research obtained from two sources of the primary and secondary data. The result showed analysis of determination coefisien $\left(\mathrm{R}^{2}\right)$ obtained value of 0,989 which means that their land, capital and labor affect production of $98,9 \%$ papaya, the remaining $1,1 \%$ influenced by other factors. The result of the analysis in union (test-f) factor that the same area of land, capital and labor had real impact on the production of papaya in district Krueng Barona Jaya Aceh Besar. In full analysis of (test-t) said that factors the same area of land, capital and labor had real impact on the production of papaya
\end{abstract}

Keywords: Production Factor, Area of Land, Capital, Labor

\section{PENDAHULUAN}

Pertanian mempunyai peranan yang sangat penting dalam perekonomian di Indonesia, terutama terhadap perluasan lapangan kerja, pemerataan kesempatan kerja dan penunjang pembangunan daerah serta pemanfaatkan sumber daya alam dan sumber daya manusia. Pembangunan subsektor tanaman pangan bertujuan untuk meningkatkan produksi guna memelihara kemantapan pangan, menciptakan potensial bagi terbukanya kesempatan kerja dan kesempatan berusaha terutama di pedesaan serta meningkatkan penerimaan devisa ekspor hasil-hasil pertanian.

Peluang perkebunan pepaya di Indonesia sangat terbuka lebar karena hampir seluruh daerah di Indonesia memiliki potensi sumber daya alam yang sangat mendukung pertumbuhan dan perkembangan tanaman pepaya. Produksi pepaya yang dihasilkan di Indonesia 90\% untuk konsumsi dalam negeri, sedangkan sisanya adalah untuk ekspor. 
Buah pepaya sudah di ekspor ke beberapa negara seperti Singapura, Australia, Korea selatan, Arab saudi, Prancis dan Belanda walaupun masih dalam jumlah yang relatif kecil.

Kabupaten Aceh Besar sebagai salah satu daerah penghasil pepaya di Provinsi Aceh. Dengan luas areal penanaman pepaya sebesar $19 \mathrm{Ha}$. Salah satu sentra penghasil pepaya adalah Kecamatan Krueng Barona Jaya di Kabupaten Aceh Besar.

Berikut adalah tabel data produksi pepaya di Kecamatan Krueng Barona Jaya yang diperoleh dari Dinas Pertanian Tanaman Pangan dan Hortikultura Kabupaten Aceh Besar. Dimana luas Kecamatan Krueng Barona Jaya seluas 906 Ha yang terdiri dari 3 mukim dan 12 gampong. Berikut adalah produksi pepaya di Kecamatan Krueng Barona Jaya dari tahun 2011 sampai dengan tahun 2015.

hasil produksi pepaya di Kecamatan Krueng Barona Jaya yang memberikan hasil produksi pada tahun 2010 sebesar 4 ton, pada tahun 2011 dan 2012 hasil produksi meningkat sebesar 10,6 ton, pada tahun 2013 hasil produksi pepaya terjadi peningkatan lagi sebesar 19,2 ton, namun pada tahun 2014 dan 2015 hasil produksi pepaya menurun 6 ton dari tahun sebelumnya, maka hasil produksinya sebesar 18,6 ton. Meski begitu pada tahun kedua dan seterusnya termasuk hasil produksi yang tertinggi dari tahun pertama. Hal ini menandakan bahwa peningkatan produksi tiap tahunnya mengalami peningkatan yang belum maksimal. Hal ini juga mempengaruhi pendapatan petani di Kecamatan Krueng Barona Jaya dan kecamatan lainnya yang berada di Kabupaten Aceh Besar.

Namun pada tahun 2014 hama belalang mengancam tanaman dan telah mengakibatkan turunnya produksi pepaya milik petani di kawasan bantaran Krueng (sungai) Aceh kawasan Cot Irie, Kecamatan Barona Jaya, Kabupaten Aceh Besar. Hasil panen pertama cukup memuaskan dan lahan tanaman pepaya milik petani pada tahun-tahun biasanya dapat memanen dua hingga tiga buah setiap pohon. Namun terdapat masalah yang dihadapi para petani yaitu tidak meningkatnya biaya produksi, luas lahan yang semakin sempit serta kurangnya tenaga kerja berkualitas sehingga mengakibatkan hasil produksi menurun dan kualitas buah kurang bermutu. Berdasarkan latar belakang di atas maka penulis tertarik melakukan penelitian dengan judul "Analisis Faktor-Faktor Yang Mempengaruhi Produksi Usahatani Pepaya Di Kecematan Krueng Barona Jaya Kabupaten Aceh Besar”.

Tujuan dilaksanakannya penelitian ini adalah untuk mengetahui pengaruh faktor luas lahan, modal, dan tenaga kerja terhadap produksi pepaya di Kecamtan Krueng Barona Jaya Kabupaten Aceh Besar.

\section{Lokasi dan Waktu Penelitian}

\section{METODE PENELITIAN}

Penelitian ini dilakukan di Kecamatan Krueng Barona Jaya Kabupaten Aceh Besar. Objek penelitian ini adalah para petani pepaya di Kecamatan Krueng Barona Jaya Kabupaten Aceh Besar. Penentuan lokasi ini dilakukan secara sengaja (total sampling) berdasarkan pertimbangan bahwa Kecamatan Krueng Barona Jaya Kabupaten Aceh Besar merupakan salah satu wilayah yang memproduksi pepaya.

\section{Objek dan Ruang Lingkup Penelitian}

Objek penelitian adalah petani pepaya. Ruang lingkup penelitian ini terbatas pada respon petani terhadap faktor luas lahan, modal dan tenaga kerja yang mempengaruhi poduksi pepaya

Analisis faktor-faktor yang mempengaruhi produksi pepaya di kecamatan Krueng Barona Jaya 


\section{Sumber dan Metode Pengumpulan Data}

Metode yang dilakukan dalam penelitian ini adalah metode survey. Yaitu penyelidikan yang dilakukan untuk memeperoleh fakta-fakta dari gejala-gejala yang ada, baik tentang institusi sosial dan ekonomi dari suatu kelompok ataupun suatu daerah (Nazir, 2005).

Jumlah populasi dalam penelitian ini adalah 15 orang. Penentuan sampel dilakukan secara keseluruhan populasi sampel (total sampling). Total sampling adalah teknik penentuan sampel bila anggota populasi digunakan sebagai sampel. Hal ini sering digunakan bila jumlah populasi relatif kecil, kurang dari 30 orang

Pengumpulan data yang dilakukan dalam penelitian ini diperoleh dari 2 sumber, yaitu data primer dan data sekunder. Data primer diperoleh wawancara langsung dengan para petani yang mengelola usahatani pepaya di Kecamatan Krueng Barona Jaya Kabupaten Aceh Besar. Sedangkan data sekunder diperoleh dari studi dan lembaga terkait dengan penelitian ini.

\section{Model Analisis}

Data yang telah dikumpulkan dilapangan selanjutnya diolah dan ditabulasi dan dianalisis sesuai dengan kebutuhan analisis yang dapat digambarkan dengan fungsi seperti yang terlihat dibawah ini :

$$
\mathrm{Q}=\alpha_{0}+\alpha_{1} \mathrm{LL}+\alpha_{2} \mathrm{M}+\alpha_{3} \mathrm{TK}+\mathrm{e}_{1}
$$

Dimana :

$$
\begin{aligned}
& \mathrm{Q} \quad \text { = Jumlah Produksi pepaya di Kecamatan Krueng Barona Jaya } \\
& \mathrm{LL} \quad=\text { Luas Lahan tanaman pepaya di Kecamatan Krueng Barona Jaya } \\
& \mathrm{M} \quad=\text { Modal yang digunakan untuk produksi tanaman pepaya } \\
& \mathrm{TK} \quad=\text { Tenaga Kerja } \\
& \begin{array}{c}
\alpha_{0} \quad=\text { Konstanta produksi pepaya di Kecamatan Krueng Barona Jaya } \\
\alpha_{1 . .} \alpha_{3} \quad=\text { Koefesien regresi } \\
\mathrm{e}_{1}=\text { Faktor yang tidak terobservasi (error) }
\end{array}
\end{aligned}
$$

\section{Uji kesuaian Model}

Selanjutnya untuk pengujian validitas dari hasil taksiran tersebut digunakan uji koefisien R2, uji serempak F statistik dan uji t statistik. Suatu perhitungan statistik disebut signifikan secara statistik apabila nilai statistiknya berada pada daerah dimana $\mathrm{H}_{0}$ ditolak. Sebaliknya disebut tidak signifikan bila uji statistiknya berada pada daerah dimana $\mathrm{H}_{0}$ diterima.

\section{Uji Determinasi $\left(\mathbf{R}^{2}\right)$}

Penilaian terhadap koefisien determinasi $\left(\mathrm{R}^{2}\right)$ bertujuan untuk melihat variabel kemampuan variabel bebas dalam menjelaskan pengaruhnya terhadap variabel terikat. Selanjutnya untuk menguji keeratan hubungan antara variabel bebas dengan variabel terikat digunakan Koefisien Determinasi $\left(\mathrm{R}^{2}\right)$, dengan rumus sebagai berikut (Sudjana, 2006) : 


$$
\mathrm{R}^{2}=\frac{\mathrm{JK}(\mathrm{reg})}{\sum y i^{2}}
$$

Dimana :

$\mathrm{R}^{2} \quad=$ Koefisiensi Determinasi

JK $($ reg $)=$ Jumlah Kuadrat untuk Regresi

Yi = Jumlah kuadrat total

\section{Uji-F Statistik}

Uji signifikan simultan pada dasarnya menunjukan apakah semua variabel independen yang dimasukkan dalam model mempunyai pengaruh secara serentak terhadap variabel dependen.

Untuk menguji pengaruh variabel bebas sacara serempak / simultan terhadap variabel terikat digunakan uji F dengan sebagai berikut (Sudjana,1992)

$$
\boldsymbol{F} \text { hitung }=\frac{\mathbf{R}^{2} / \mathbf{k}}{\left(\mathbf{1}-\mathbf{R}^{2}\right)(\mathbf{n}-\mathbf{k}-\mathbf{1})}
$$

Dimana $: \mathrm{R}^{2}=$ Koefisien Determinasi

$\mathrm{k}=$ Jumlah Variabel Bebas

$\mathrm{n}=$ Jumlah Sample

Dengan kaedah keputusan :

Jika $\mathrm{F}$ (hitung) > F (table), pada taraf nyata 0,05 maka terima Ha dan tolak Ho, artinya variabel-variabel bebas mempunyai pengaruh nyata (significant) terhadap variabel terikat. Sebaliknya jika $F$ (hitung) $\leq \mathrm{F}$ (table), pada taraf nyata 0,05 maka terima Ha dan tolak Ho, artinya variabel-variabel bebas mempunyai tidak pengaruh nyata (nonsignificant) terhadap variabel terikat.

Dimana hipotesis :

Ho : ai $=0$; Variabel bebas berpengaruh tidak nyata terhadap variabel terikat

Ha : ai $\neq 0$; Variabel bebas berpengaruh nyata terhadap variabel terikat.

\section{Uji Statistik t-parsial}

Untuk menguji apakah masing-masing pengaruh oksogen berpengaruh nyata atau tidak terhadap variabel endogen, maka digunakan uji statistik $t$ dengan membandingkan $t$ hitung dengan $t$ table.

Untuk menguji pengaruh variabel bebas, secara parsial digunakan uji t dengan rumus sebagai berikut (Sudjana, 2006) :

$$
\mathbf{t}_{\text {hit }}=\frac{a i}{S a i}
$$

Dimana $\mathrm{t}=\mathrm{Uji}$ secara parsial 


$$
\begin{aligned}
& \mathrm{a}_{\mathrm{i}}=\text { Koefesien regresi } \\
& \mathrm{S}=\text { Standar deviasi }
\end{aligned}
$$

Dimana hipotesis :

Ho : ai $=0$; Variabel bebas berpengaruh tidak nyata terhadap variabel terikat

Ha : ai $\neq 0$; Variabel bebas berpengaruh nyata terhadap variabel terikat.

Hipotesis ini diuji dengan uji t pada daerah krisis dengan taraf nyata sebesar $\alpha=5 \%$ secara dua arah. Nilai t-statistik dapat juga dilihat dari probabilitas (p-value). Jika nilai pvalue lebih kecil dari $\alpha$, maka $\mathrm{H} 0$ ditolak, dan sebaliknya $\mathrm{H} 0$ diterima jika nilai $\mathrm{p}$-value lebih besar dari $\alpha$.

\section{HASIL PENELITIAN DAN PEMBAHASAN \\ 1. Faktor-Faktor Yang Mempengaruhi Produksi Pepaya \\ A. Produksi}

Produksi merupakan hasil akhir yang diperoleh dari suatu proses produksi. Produksi pepaya diperoleh dari kegiatan mengkombinasikan faktor-faktor produksi seperti luas lahan, modal dan tenaga. Besar kecilnya produksi pepaya sangat mempengaruhi terhadap pendapatan usahatani pepaya. Adapun rata-rata produksi pepaya di Kecamatan Krueng Barona Jaya Kabupaten Aceh Besar adalah sebagai berikut :

Tabel 1. Produksi Pepaya di Kecamatan Krueng Barona Jaya Kabupaten Aceh Besar, Tahun 2017

\begin{tabular}{ccc}
\hline Produksi $(\mathbf{K g} / \mathbf{H a})$ & Jumlah Sampel (Orang) & Persentase $\mathbf{( \% )}$ \\
\hline $18.000-20.000$ & 6 & 40 \\
$21.000-23.000$ & 5 & 33,33 \\
$>24.000$ & 4 & 26,66 \\
\hline Total & $\mathbf{1 5}$ & $\mathbf{1 0 0}$
\end{tabular}

Sumber : Data Primer 2016 (diolah)

Berdasarkan tabel diatas dapat dilihat bahwa sebanyak 4 orang atau 33,33\% dari 15 orang sampel memperoleh produksi pepaya diatas $24.000 \mathrm{~kg} / \mathrm{ha}$. Sedangkan rata-rata produksi pepaya adalah berkisar diatas 18.000 - 20.000 dengan persentase sebesar $40 \%$ dan jumlah sampel mencapai 6 orang.

\section{B. Luas Lahan}

Luas lahan adalah luas lahan yang diusahakan para petani sebagai tempat bercocok tanam pepaya. Luas lahan merupakan faktor yang sangat penting dalam usahatani untuk meningkatkan produksi yang akan mempengaruhi pendapatan dan keuntungan yang akan diterima oleh para petani.

Penggunaan luas lahan di daerah penelitian bervariasi. Untuk melihat rincian luas lahan tanam petani sampel tercantum dalam lampiran. sedangkan rata-rata penggunaan luas lahan garapan petani sampel dapat dilihat pada tabel 2 . 
Tabel 2. Luas Lahan Tanaman Pepaya Petani Sampel di Kecamatan Krueng Barona Jaya Kabupaten Aceh Besar, Tahun 2017

\begin{tabular}{ccc}
\hline Luas Lahan (Ha) & Jumlah Sampel (Orang) & Persentase (\%) \\
\hline $0,8-1,2$ & 8 & 53,33 \\
$1,3-1,5$ & 3 & 20 \\
$>1,7$ & 4 & 26,66 \\
& & \\
\hline Total & $\mathbf{1 5}$ & $\mathbf{1 0 0}$
\end{tabular}

Sumber : Data Primer 2017 (diolah)

Dari Tabel 2 dapat dilihat bahwa 48 orang sampel secara keseluruhan terdapat sebanyak 8 orang sampel dengan luas lahan $0,8-1,2 \mathrm{Ha}$ atau 53\%. Hal ini menunjukkan bahwa luas lahan pepaya di Kecamatan Krueng Barona Jaya rata-rata kurang dari 1,7 Ha.

\section{Modal}

Modal merupakan unsur utama dalam usaha perkebunan yang penting digunakan untuk mengubah produksi dan pendapatan. Modal yang dimaksudkan dalam penelitian ini adalah jumlah biaya variabel yang digunakan petani dalam suatu proses produksi. Besar kecilnya jumlah modal yang dimiliki petani akan berpengaruh kepada produksi yang diperolehnya.

Tabel 3. Modal Usahatani Pepaya Petani Sampel di Kecamatan Krueng Barona Jaya Kabupaten Aceh Besar, Tahun 2017

\begin{tabular}{ccc}
\hline Modal (Rp/Produksi) & Jumlah Sampel (Orang) & Persentase (\%) \\
\hline $2.000 .000-3.000 .000$ & 7 & 46,66 \\
$3.000 .000-4.000 .000$ & 6 & 40 \\
$>4.000 .000$ & 2 & 13,33 \\
& & $\mathbf{1 0 0}$ \\
\hline Total & $\mathbf{1 5}$ &
\end{tabular}

Sumber : Data Primer 2017 (diolah)

Tabel diatas dapat kita lihat tingkat modal yang digunakan petani pada usahatani pinang sangat bervariasi, akan tetapi secara umum rata-rata modal yang digunakan oleh petani sampel berkisar antara Rp. 2.000.000 - Rp. 3.000.000 dengan jumlah petani sampel sebanyak 7 orang atau sekitar $46,66 \%$ dari keseluruhan sampel.

\section{Tenaga Kerja}

Selain faktor luas lahan dan modal pada usahatani pepaya yang mempengaruhi produksi usahatani pepaya, factor tenaga kerja juga sangat mempengaruhi produksi pepaya, dimana peran tenaga kerja sangatlah penting dan krusial, sehingga keberadaan tenaga kerja sangat penting dan berpengaruh terhadap produksi usahatani pepaya. Adapun jumlah penggunaan tenaga kerja pada usahatani pinang di Kecamatan Krueng Barona Jaya dapat dilihat pada tabel 2 . 
Tabel 4. Jumlah Tenaga Kerja Pada Usahatani Pepaya Pada Setiap Petani Sampel di Kecamatan Krueng Barona Jaya Kabupaten Aceh Besar, Tahun 2017

Tenaga Kerja (HKP) Jumlah Sampel (Orang) Persentase

$\begin{array}{ccc}65,38-84,63 & 6 & 40 \\ 97,88-110,18 & 5 & 33,33 \\ 116,18-124,88 & 4 & 26,66\end{array}$

\section{Total}

15

100

Sumber : Data Primer 2017 (Diolah)

Berdasarkan Tabel 11 dapat dilihat penggunaan tenaga kerja oleh para petani usahatani pepaya, dimana rata-rata penggunaan tenaga kerja sebanyak 97,05 HKP per tahun, dimana penggunaan paling rendah yaitu 65,38 - 84,63 HKP per Hektar per tahun sebanyak 6 orang petani, sedang penggunaan tenaga kerja paling banyak yaitu 116,18-124,88 HKP per hektar per tahun dengan jumlah responden sebanyak 4 orang.

2. Analisis Faktor Luas Lahan, Modal, dan Tenaga Kerja yang mempengaruhi Produksi Pepaya di Kecamatan Krueng Barona Jaya Kabupaten Aceh Besar

Model analisis yang digunakan untuk menganalisis faktor-faktor yang mempengaruhi produksi pinang di Kecamatan Krueng Barona Jaya Kabupaten Aceh Besar yaitu menggunakan model regresi linier berganda. Produksi dijadikan sebagai variabel tak bebas (dependentvariable). Variabel lain yang dimasukkan kedalam adalah variabel bebas (independent variable), seperti ; luas lahan (LL), modal (M), tenaga kerja (TK). Persamaan regresinya yaitu sebagai berikut :

$$
\mathrm{Q}=\alpha_{0}+\alpha_{1} \mathrm{LL}+\alpha_{2} \mathrm{M}+\alpha_{3} \mathrm{TK}+\mathrm{e}_{1}
$$

Produksi pepaya mempunyai hubungan dengan faktor luas lahan, modal dan tenaga kerja. Untuk mengetahui besarnya pengaruh faktor tersebut terhadap produksi pepaya, maka analisis menggunakan model regresi linier berganda, sehingga diperoleh hasil sebagai berikut :

Tabel 5. Hubungan Antara Variabel Dependen dan Variabel Independent

\begin{tabular}{llrrr}
\hline \multicolumn{1}{c}{ Variable } & \multicolumn{1}{c}{ Namavariabel } & Koefisien & \multicolumn{2}{c}{ T } \\
\hline Ao & (constant) & 11352.068 & 27,656 & 0,000 \\
LL & Luas Lahan & 1863.646 & 2,208 & 0,049 \\
M & Modal & 0,0002 & 3,215 & 0,008 \\
TK & Tenaga Kerja & 41.535 & 2,814 & 0,017 \\
\hline
\end{tabular}

$\mathrm{R}^{2}: 0.989$

F Hitung : 325.206

F Tabel : 3.98

T Tabel : 2.17881

Sumber: Data primer (diolah 2017)

Dari table perhitungan statistic di atas maka di dapat persamaan regresi sebagai berikut :

$$
\mathrm{Q}=1207,0540+661,9064 \mathrm{LL}+00,0001 \mathrm{M}+0,2241 \mathrm{TK}+\mathrm{e}_{1}
$$


Berdasarkan koefisien regresi dari masing-masing variable bebas pada persamaan tersebut, dapat disimpulkan apabila variabel luas lahan, modal dan tenaga kerja berada dalam keadaan yang konstan, maka akan meningkatkan produksi pepaya sebesar 11352.068 $\mathrm{Kg} / \mathrm{tahun}$.

Untuk melihat secara statistik hasil pengujian koefisien determinasi $\left(\mathrm{R}^{2}\right)$, pengujian secara serempak (uji-F), pengujian secara parsial dan koefisien (pengaruh dari masingmasing variable bebas). Maka di jelaskan sebagai berikut :

\section{A. $\quad \mathbf{R}^{2}$ (R Square)}

Secara serempak hasil analisa korelasi diperoleh koefisien determinasi $\left(\mathrm{R}^{2}\right)$ sebesar 0,989 yang berarti bahwa 98,9 persen variasi perubahan produksi pepaya dipengaruhi oleh faktor luas lahan, modal dan tenaga kerja. Sedangkan sisanya 1,1 persen dipengaruhi oleh faktor-faktor lain diluar faktor-faktor didalam penelitian ini. Hal ini menunjukkan hubungan yang erat antara produksi pepaya dengan faktor luas lahan, modal dan tenaga kerja pada usahatani pepaya di Kecamatan Krueng Barona Jaya Kabupaten Aceh Besar.

\section{B. Uji Serempak (F)}

Hasil uji serempak menggunakan uji "F" fungsi linier berganda diperoleh $F_{h i t u n g}=$ 325,206 sedangkan $F_{\text {tabel }}=3.98$ sehingga dapat disimpulkan bahwa $F_{\text {hitung }}>F_{\text {tabel. }}$. Hal ini menunjukkan bahwa luas lahan, modal, dan tenaga kerja secara bersama-sama berpengaruh nyata terhadap produksi pepaya (terima $\mathrm{H}_{\mathrm{a}}$ tolak $\mathrm{H}_{0}$ ).

\section{Ujiparsial ( $\mathbf{T}$ )}

Untuk melihat secara statistic tingkat signifikan koefisien regresi (pengaruh dari masing-masing variable independent), maka diuji secara terpisah (parsial) antara variable independent terhadap variable dependent denganuji-t. hasil pengujian secara parsial atau uji$\mathrm{t}$ bagi setiap variable dengan tingkat kepercayaan 95\% (taraf nyata $=5 \%$ ) adalah sebagai berikut:

\section{a. Luas Lahan}

Nilai koefisien luas lahan yaitu 1863.646, menunjukkan bahwa setiap benambahan 1 ha luas lahan, maka akan meningkatkan produksi pinang sebesar $1863.646 \mathrm{Kg}$. Hal ini disebabkan karena semakin luas areal lahan yang kita usahakan, maka semakin meningkat pula populasi pepaya yang didapatkan. Artinya apabila populasinya banyak maka akan menghasilkan produksi yang besar pula.

Hasil analisis terhadap variable luas lahan diperoleh $t_{\text {hitung }}=2,208$ sedangkan $t_{\text {tabel }}=$ 2.17881, hal ini menunjukkan $t_{\text {hit }}>t_{\text {tabel. }}$. Dari hasil perhitungan ini menunjukkan bahwa variable luas lahan berpengaruh nyata terhadap produksi pepaya, dimana semakin tinggi luas lahan semakin meningkatnya produksi pepaya yang didapat.

\section{b. Modal}

Nilai koefisien modal yaitu 0,0002 menunjukkan bahwa setiap penambahan 1 ribuan modal, maka akan meningkatkan produksi pepaya sebesar $0,0002 \mathrm{~kg}$. Tapi dari uji statistik diperoleh $t_{\text {hitung }}=3,215$ sedangkan $t_{\text {tabel }}=2.17881$, menunjukkan bahwa variable modal berpengaruh nyata terhadap produksi pepaya, dimana modal pepaya di tempat penelitian ini adalah bibit, pupuk, pestisida dan modal tetap dan sebagainya artinya walaupun modal ditambah maka produksi tidak akan meningkat secara nyata. Hal ini sebabkan modal usaha merupakan salah satu faktor penting dalam meningkatkan produktivitas tanaman, dimana dengan adanya modal yang cukup, maka para petani mampu memenuhi kebutuhan dalam pengembangan tanaman 
pepaya seperti penyediaan pupuk, bibit dan tenaga kerja yang berkualitas sehingga akan mendorong tanaman untuk dapat berproduksi secara maksimal.

c. Tenaga Kerja

Nilai koefisien tenaga kerja yaitu 41.535, menunjukkan bahwa setiap penambahan tenaga kerja sebesar $1 \mathrm{HKP}$, maka produksi pepaya akan meningkat sebesar 41.535 $\mathrm{Kg}$. Hal ini menggambarkan bahwa penggunaan tenaga kerja pada usahatani pepaya di daerah penelitian sangat dibutuhkan, hal ini menggambarkan bahwa kondisi usahatani pepaya masih sangat sederhana dikarenakan pengelolaan usahatani pepaya bersifat sederhana.

Hasil analisis terhadap variable tenaga kerja diperoleh $t_{\text {hitung }}=2,814$ sedangkan $t_{\text {tabel }}=$ 2.17881, hal ini menunjukkan bahwa $t_{\text {hitung }}>t_{\text {tabel. }}$. Hal ini disebabkan penggunaan tenaga kerja pada usahatani pinang di daerah penelitian telah sesuai dengan kebutuhan petani, sehingga usaha untuk memaksimalkan penggunaan tenaga kerja masih dapat ditingkatkan oleh para petani. Sehingga para petani dapat menggunakan tenaga kerja optimal.

\section{Kesimpulan}

\section{KESIMPULAN DAN SARAN}

Adapun kesimpulan dari penelitian ini adalah sebagai berikut:

1. Hasil analisis koefisiensi determinasi ( $\mathrm{R}^{2}$ ) diperoleh nilai sebesar 0,989 yang berarti bahwa luas lahan, modal, dan tenaga kerja mempengaruhi produksi pepaya sebesar $98,9 \%$, sedangkan sisanya $1,1 \%$ dipengaruhi oleh faktor lain.

2. Hasil analisis secara serempak (uji-f) bahwa faktor luas lahan, modal, dan tenaga kerja berpengaruh nyata terhadap produksi pepaya di Kecamatan Krueng Barona Jaya Kabupaten Aceh Besar. Analisis secara parsial (uji-t) menyatakan bahwa faktor luas

\section{Saran} lahan dan modal, dan tenaga kerja berpengaruh nyata terhadap produksi pepaya.

Berdasarkan analisis dan pembahasan sebelumnya, untuk mendukung produksi Pepaya di Kecamatan Krueng Barona Jaya, maka peneliti ingin memberikan sumbangan pemikiran berupa saran yaitu

1. Untuk meningkatkan produksi tanaman pepaya di Kecamatan Krueng Barona Jaya Kabupaten Aceh Besar, petani pepaya sebaiknya dapat membudidayakan pepaya dengan teknik budidaya yang lebih tepat serta menigkatkan kualitas tenaga kerja dan luas lahan.

2. Untuk menigkatkan produksi tanaman pepaya hendaknya petani memperhatikan penggunaan kualitas tenaga kerja modal dan luas lahan serta biaya produksi sehingga secara keseluruhan mampu meningkatkan jumlah produksi yang sesuai.

\section{DAFTAR PUSTAKA}

A.Tohir, Kaslan. 1991. Seuntai Pengetahuan Usahatani Indonesia. Rineka Cipta. Jakarta Abdurrahman, Dudung. 1999. Metode Penelitian Sejarah. PT Logos Wacana Ilmu. Jakarta.

A.M Sadirman. 2009. Interaksi dan Motivasi Belajar Mengajar. PT Rajawali Pers. Jakarta Badan Pusat Statistik. 2010-2015. Aceh Besar Dalam Angka. BPS Kabupaten Aceh Besar, Banda Aceh.

Daniel. 2002. Pengantar Ekonomi Pertanian. Bumi Aksara. Jakarta.

Kuncoro, Mudrajad 2009. Metode Riset Untuk Bisnis dan Ekonomi. Erlangga. Jakarta Moehar. 2001. Pengantar Ekonomi Pertanian. Bumi Aksara. Jakarta 
Mulyadi. 2003. Ekonomi Sumber Daya Manusia Dalam Perspektif Pembangunan. Raja Grafindo Persada. Jakarta

Nazir, M. 2005. Metode Penelitian. Ghalia Indonesia. Jakarta.

Pracoyo. T.K. 2006. Aspek Dasar Ekonomi Mikro. PT. Grasindo. Jakarta.

Riyanto, B. 2001. Dasar-dasar Pembelajaran Perusahaan. Yayasan Bada Gajah Mada.Yogyakarta.

Soekartawi. 1990. Teori Ekonomi Produksi, Dengan Pokok Bahasan Analisis $\quad$ Fungsi Cobb-Douglass. Rajawali Pers, Jakarta.

Soekartawi. 1993. Prinsip Dasar Ekonomi Pertanian, Teori dan Aplikasi. Edisi $\quad$ Revisi. Penerbit Rajawali, Jakarta.

Soekartawi.2002. Prinsip Dasar Ekonomi Pertanian Teori Dan Aplikasinya. Raja Grafindo Persada. Jakarta.

Sudjana. 2006. Metoda Statistika. Tartiso. Bandung.

Sukirno. Sadono. 2000. Makro Ekonomi Modern Perkembangan Pemikiran Klasik dan Kesenian Baru. PT Raja Grafindo Persada, Jakarta. 